\title{
ANALISA PERBANDINGAN BREADTH-FIRST SEARCH DAN DEPTH- FIRST SEARCH PADA APLIKASI SISTEM PAKAR PENGOBATAN TRADISIONAL
}

\author{
Ifrisima, Anton Setiawan H, Nurcahyani Dewi \\ Jurusan Teknik Informatika \\ Sekolah Tinggi Teknologi Adisutjipto Yogyakarta \\ informatika@stta.ac.id
}

\begin{abstract}
This research was conducted based on the need for tools for parents who have had children in determining a traditional medicine to treat illnesses suffered by children, toddlers and babies. Aids in the form of an expert system of traditional medicine. This expert system application can be run in a way that the disease name input experienced by children, toddlers and babies, then the expert system will provide information prescription medications to treat the disease. Search method used is the method of Breadth-First Search and Depth-First Search. Results of comparative analysis of Breadth-First Search and Depth-First Search was concluded that the analysis using the Depth-First Search more quickly provide information about traditional medicine in comparison with using the method of Breadth-First Search. However, the use of the method of Breadth-First Search is superior compared with Depth-First Search. This is because the method of Breadth-First Search will not find a dead end or to find a solution although it has only one solution. And if you have two solutions, the method of Breadth-First Search will find them. The test results of the application of expert system of traditional medicine in the 30 responders was $72.67 \%$. Thus, the application of expert system of traditional medicine by using Breadth-First Search and Depth-First Search good.
\end{abstract}

Keywords: Expert System, Traditional Medicine, Breadth-First Search, Depth First Search

\section{Latar Belakang Masalah}

Pemilihan masalah menyangkut pengobatan tradisional dapat dijadikan sistem pakar, hal ini dilihat dari banyaknya orang yang tidak sesuai dengan pengobatan secara medis terutama bagi mereka yang alergi terhadap obat-obatan (kimia) tertentu dan kurangnya ilmu pengetahuan mengenai obat-obatan tradisional alami. Oleh karena itu dibuatlah Sistem Pakar Pengobatan Tradisional yang memperhatikan faktor kecepatan informasi resep obat tradisional dengan melakukan analisa perbandingan Breadth-First Search dan Depth-First Search.

\section{Tinjauan Pustaka}

Berdasarkan Penelitian yang berjudul Sistem Pakar untuk Mendiagnosa Penyakit THT Berdasarkan Gejalanya untuk Menentukan Alternatif Pengobatan Menggunakan Obat. Penelitian tersebut menggunakan metode Breadth-First Search. Diperoleh Hasil bahwa Sistem Pakar untuk diagnosis Penyakit THT, dapat bekerja sesuai yang diharapkan. Sistem dapat mengidentifikasi 23 jenis penyakit THT berdasarkan variasi input 38 gejala yang diberikan. Dengan adanya Aplikasi Sistem Pakar untuk menentukan Jenis tanaman obat yang sesuai 
dengan gejala sakit pada manusia, maka Sistem Pakar ini dapat digunakan untuk mempercepat pencarian terhadap jenis obat yang dibutuhkan pasien, sehingga pengguna yang membutuhkan informasi diagnosa penyakit THT dengan menggunakan tanaman obat bisa terpenuhi ( Suraya, 2012 )

\section{Dasar Teori}

\section{Sistem Pakar}

Sistem pakar adalah sistem berbasis komputer yang menggunakan pengetahuan, fakta, dan teknik penalaran dalam memecahkan masalah yang biasanya hanya dapat dipecahkan oleh seorang pakar dalam bidang tersebut. Sistem pakar bekerja berdasarkan pengetahuan yang dimasukkan oleh seorang atau beberapa orang pakar dalam rangka mengumpulkan informasi hingga sistem pakar dapat menemukan jawabannya. Tujuan pengembangan sistem pakar sebenarnya bukan untuk menggantikan peran manusia, tetapi mensubstitusikan pengetahuan manusia kedalam bentuk sistem, sehingga dapat digunakan oleh banyak orang (Kusrini, 2006: 11).

\section{Pengobatan Tradisional}

Menurut WHO (2002), pengobatan tradisional adalah jumlah total pengetahuan, keterampilan, dan praktek-praktek yang berdasarkan pada teori-teori, keyakinan, dan pengalaman masyarakat yang mempunyai adat budaya yang berbeda, baik dijelaskan atau tidak, digunakan dalam pemeliharaan kesehatan serta dalam pencegahan, diagnosa, perbaikan atau pengobatan penyakit secara fisik dan juga mental.

\section{Perancangan dan Analisa Sistem}

\section{Flowchart System}

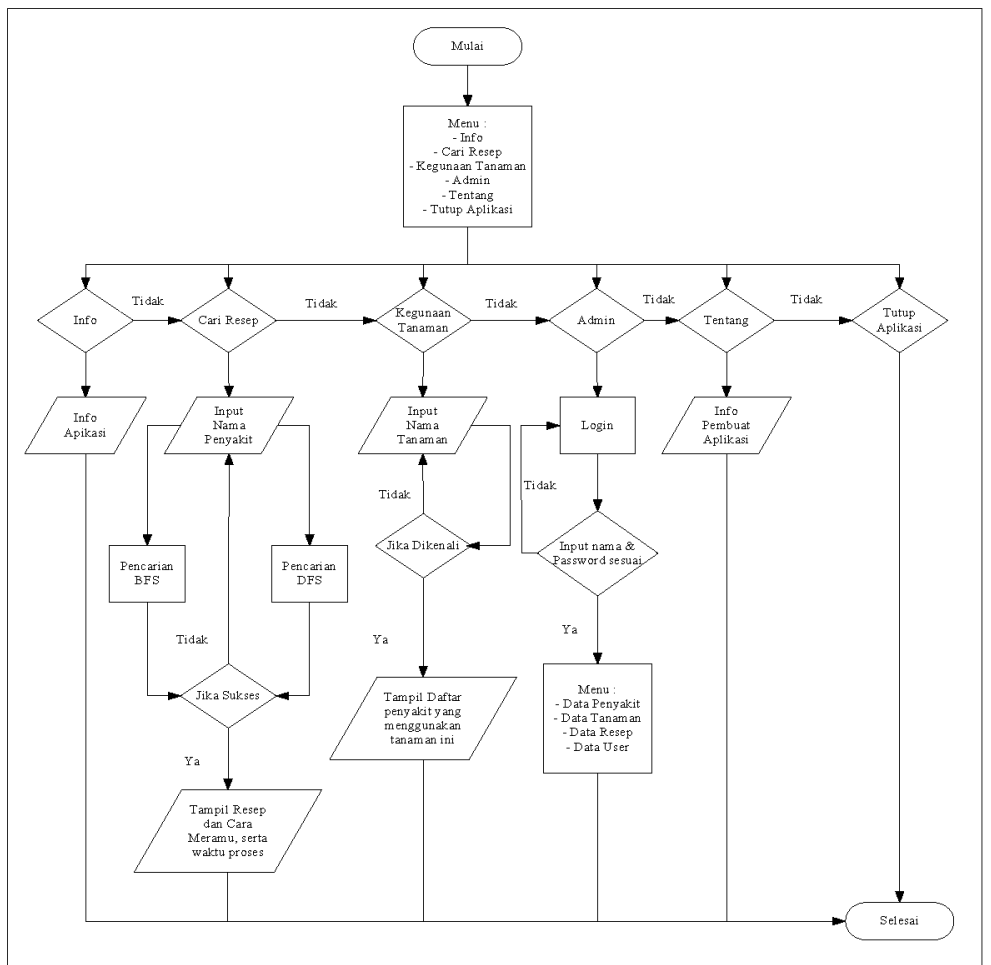

Gambar 1 Flowchart Aplikasi Sistem Pakar Pengobatan Tradisional 
Perancangan Entity Relationship Diagram (ERD)

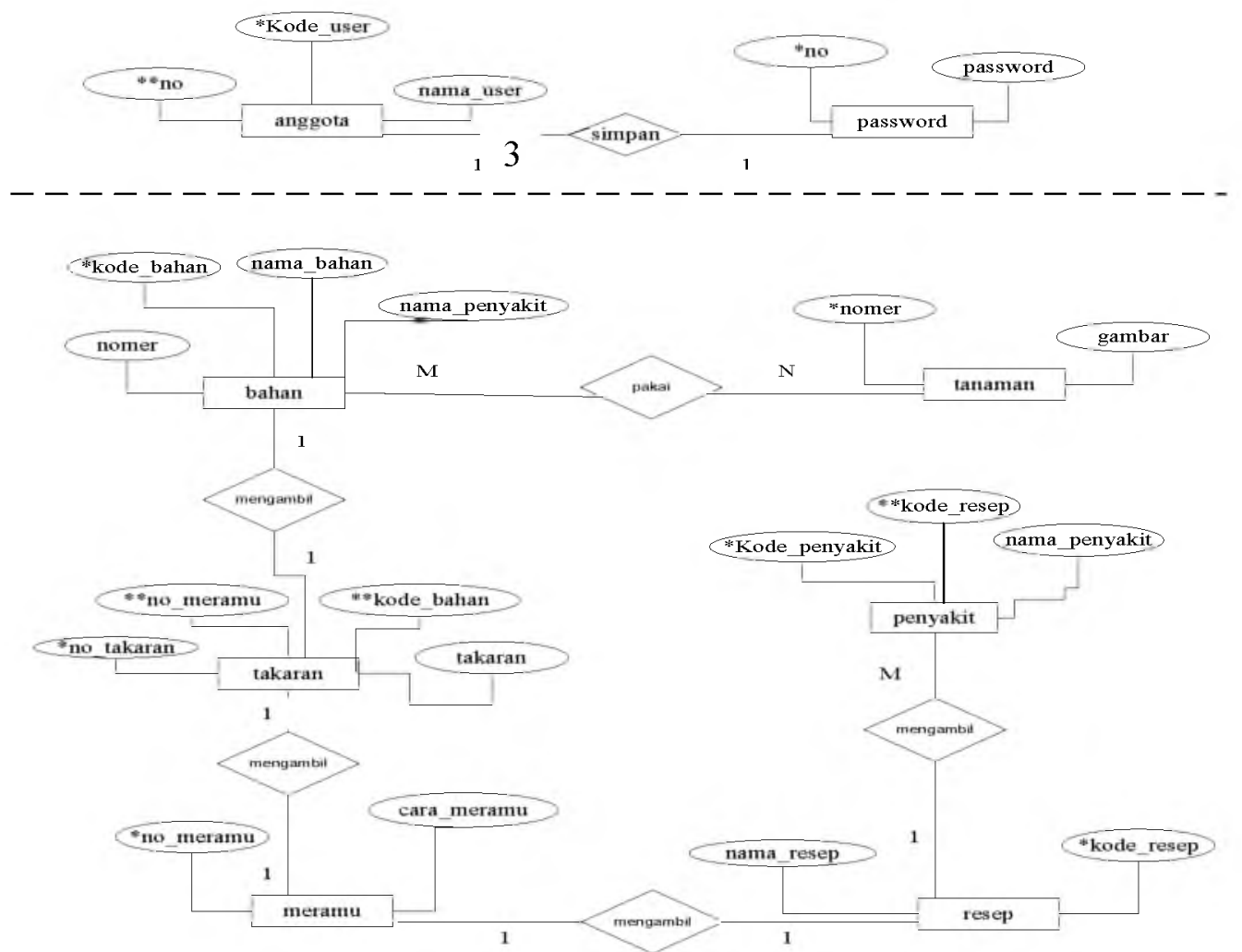

Gambar 2 ERD Aplikasi Sistem Pakar Pengobatan Tradisional

\section{Implementasi dan Analisa Hasil}

\section{Uji Fungsi Aplikasi}

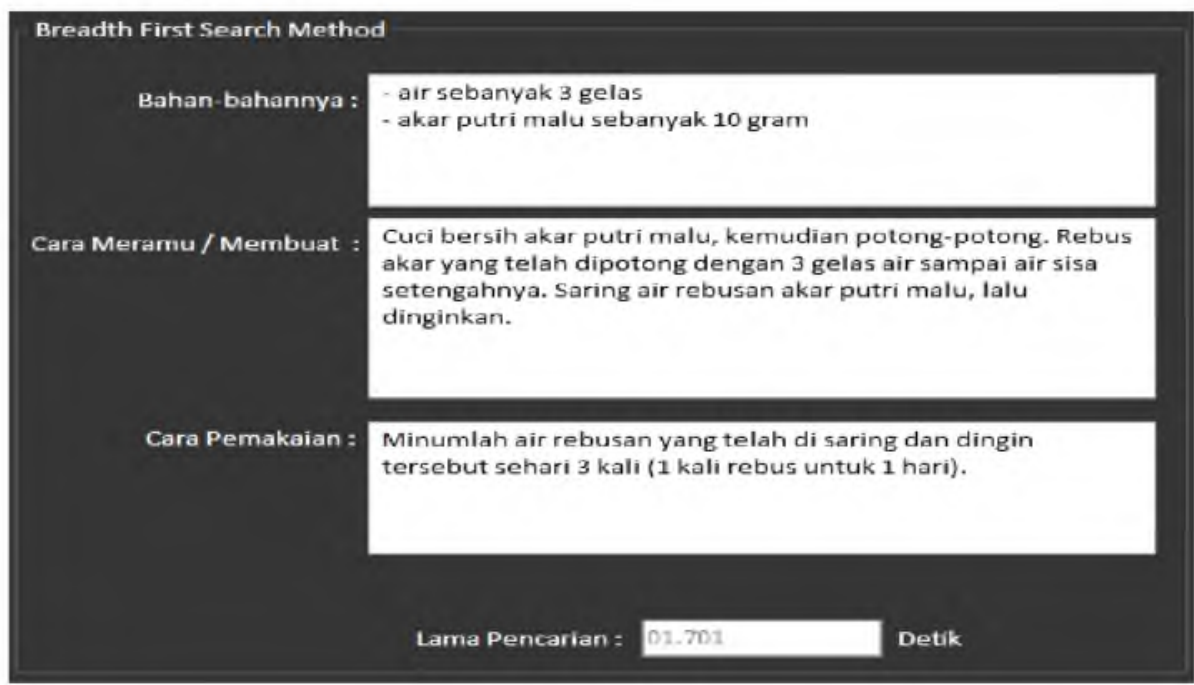

Gambar 3 Form Pencarian Menggunakan Metode Breadth-First Search

Selain itu metode Breadth-First Search juga dapat menemukan solusi lebih dari satu solusi. Analisa dilakukan pada penginputan penyakit batuk berdahak. Hasil dapat dilihat pada Gambar 4. 


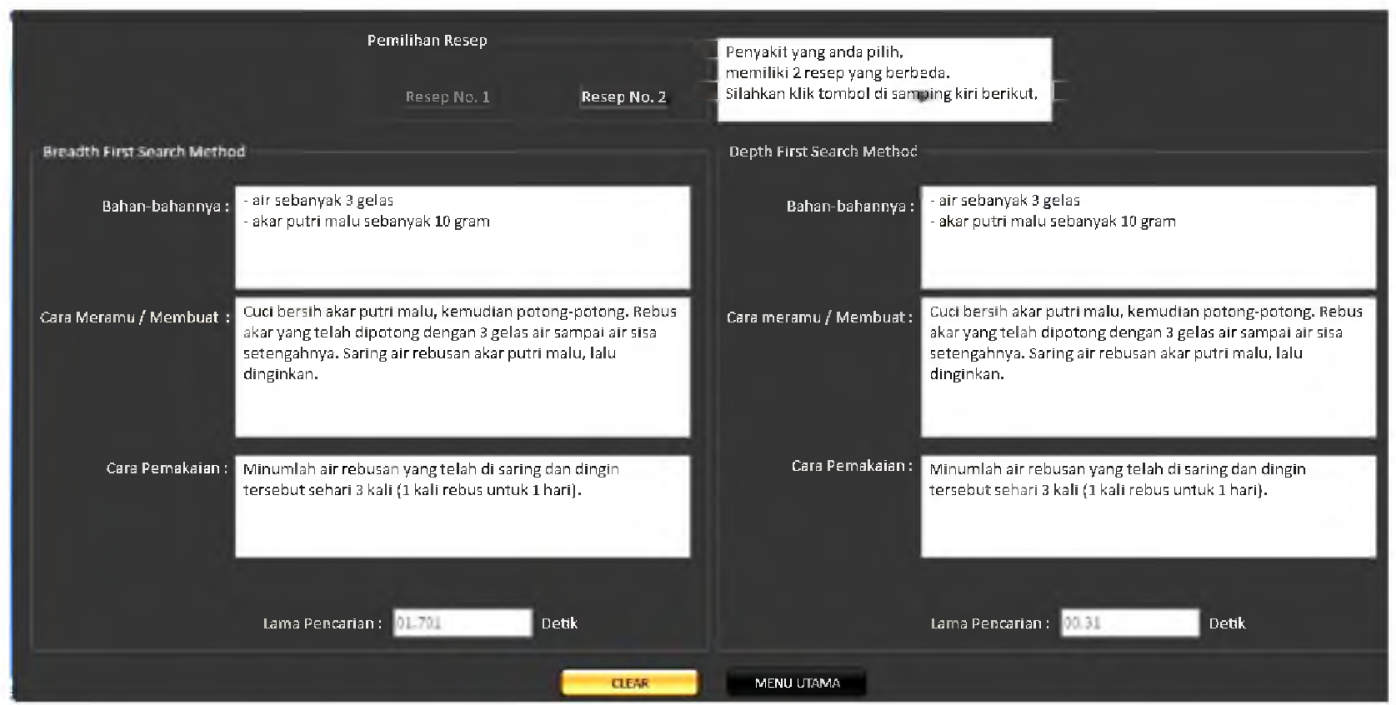

Gambar 4 Form Pencarian Menggunakan Metode Breadth-First Search

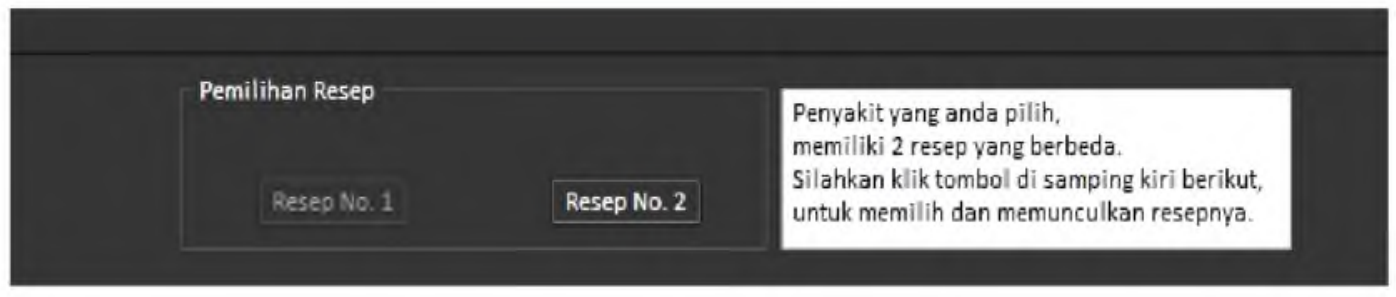

Gambar 5 Form Pencarian Menggunakan Metode Breadth-First Search

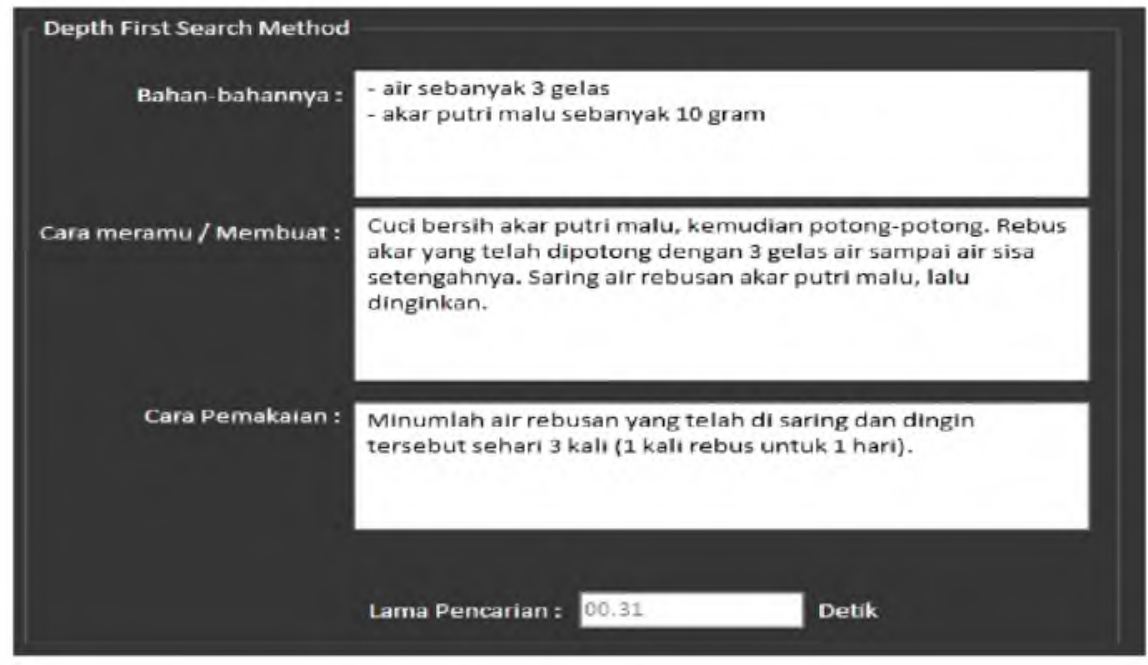

Gambar 6 Form Pencarian Menggunakan Metode Depth-First Search

Meskipun Depth-First Search memiliki waktu pencarian yang lebih pendek, akan tetapi Depth-First Search memiliki beberapa kelemahan,yaitu :

1. Pencarian menggunakan metode Depth-First Search memungkinkan tidak ditemukannya suatu solusi.

2. Jika memiliki dua solusi, Depth-First Search hanya akan menemukan satu solusi. 


\section{Uji Fungsi Pohon Biner}

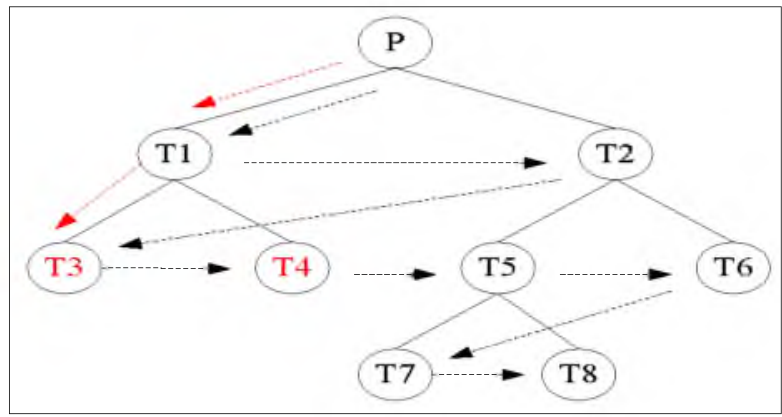

Gambar 7 Alur Pencarian Resep Batuk Berdahak 1 Sistem Pakar Pengobatan Tradisional menggunakan metode Breadth-First Search

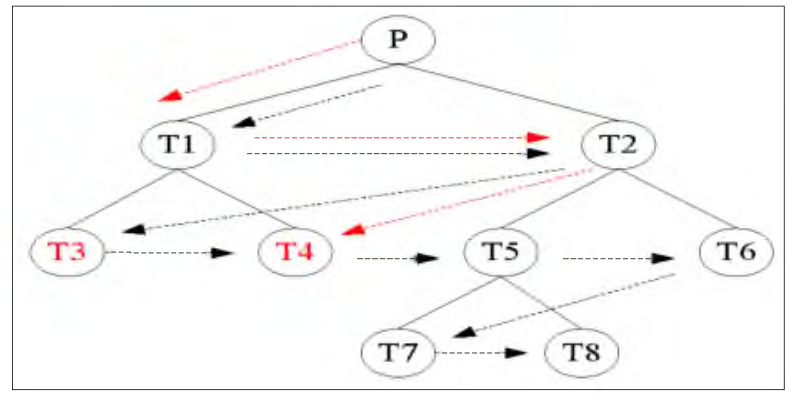

Gambar 8 Alur Pencarian Resep Batuk Berdahak 2 Sistem Pakar Pengobatan Tradisional menggunakan metode Breadth-First Search

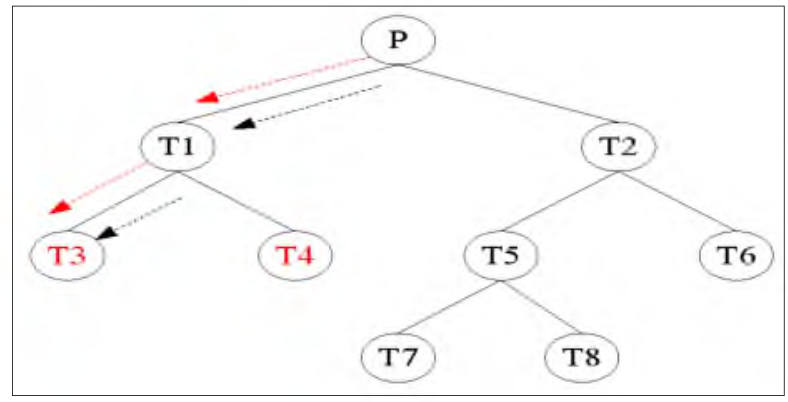

Gambar 9 Alur Pencarian Resep Batuk Berdahak Sistem Pakar Pengobatan Tradisional menggunakan metode Depth-First Search

\section{Analisa Hasil}

Berdasarkan hasil pengujian aplikasi dan pengujian pohon biner, dapat dilihat bahwa pencarian menggunakan metode Breadth-First Search memilki waktu pencarian yang lebih panjang dibandingkan dengan pencarian menggunakan metode DepthFirst Search. Akan tetapi jika dilihat dari solusi yang diberikan, metode Breadth-First Search lebih unggul dibandingkan dengan metode Depth-First Search. ini dikarenakan Breadth-First Search tidak akan menemukan jalan buntu dalam proses pencarian solusi. Dan jika sistem memiliki lebih dari satu solusi, maka Breadth-First Search akan menemukannya. Sedangkan Depth-First Search hanya unggul dalam waktu 
pencariannya saja. Ini dikarenakan Depth-First Search dapat memberikan informasi lebih cepat dibandingkan dengan Breadth-First Search, akan tetapi pencarian menggunakan metode Depth-First Search memungkinkan tidak ditemukannya solusi. Dan jika sistem memiliki dua solusi, hanya solusi pertama yang dapat ditemukan oleh Depth-First Search.

\section{Kesimpulan dan Saran}

\section{Kesimpulan}

1. Aplikasi ini dirancang agar berguna untuk memberikan informasi mengenai cara meramu bahan tradisional untuk mengobati penyakit yang diderita oleh anak, balita dan bayi.

2. Hasil uji aplikasi dan uji pohon biner menunjukkan kesimpulan bahwa analisa dengan menggunakan metode Depth-First Search lebih cepat memberikan informasi mengenai pengobatan tradisional. Meskipun demikian metode BreadthFirst Search lebih unggul dalam penggunaannya, ini dikarenakan metode BreadthFirst Search pasti akan menemukan solusi. Sedangkan metode Depth-First Search memungkinkan tidak ditemukannya solusi.

3. Hasil uji 30 responden terhadap aplikasi sistem pakar pengobatan tradisional adalah $72.67 \%$. Dengan demikian, aplikasi sistem pakar pengobatan tradisional dengan menggunakan metode Breadth-First Search dan Depth-First Search baik.

\section{Saran}

Sistem Pakar Pengobatan Tradisional ini masih dapat dikembangkan dengan penambahan resep pengobatan tradisional dengan penyakit yang umumnya diderita lansia.

\section{Daftar Pustaka}

Husni., 2004. Pemograman Database dengan Delphi. Graha Ilmu. Yogyakarta.

Jogiyanto.HM., 1990. Analisis dan Desain Sistem Informasi. Andi Offset. Yogyakarta.

Kristin Ningrum, E \& Meymurtie., 2002, Aneka Resep Obat Tradisional untuk Bayi, Balita dan Anak, Dunia Sehat. Jakarta.

Kusrini., 2006. Sistem Pakar, Teori dan Aplikasi. Andi. Yogyakarta.

Suraya., 2012. Sistem Pakar Untuk Mendiagnosa Penyakit THT Berdasarkan Gejalanya Untuk Menentukan Alternatif Pengobatan Menggunakan Tanaman Obat. Prosiding Seminar Nasional Aplikasi Sains \& Teknologi (SNAST) Periode III ISSN : 1979-911 X. Jurusan Teknik Informatika, Institut Sains \& Teknologi AKPRIND. Yogyakarta. WHO., 2002, WHO Traditional Medicine Strategy 2002-2005. World Health Organization. Geneva. 


\title{
SISTEM PENDUKUNG KEPUTUSAN PEMILIHAN BENANG RAJUT BERDASARKAN HASIL RAJUTAN MENGGUNAKAN METODE BENEFIT COST RATIO (BCR) (STUDI KASUS : KOKORO SHOP YOGYAKARTA)
}

\author{
Vetta Primastara Terryliani, Anton Setiawan H., Yuliani Indrianingsih \\ Teknik Informatika STTA Yogyakarta \\ $\underline{\text { Informatika@stta.ac.id }}$
}

\begin{abstract}
Techonology grow fastly shows many computer system thet use to solve daily problems. Yarn Selection Decision Support System (DSS) is one of system that used to select the correct yarn. This system implementation in a home industry which work in handmade sector, knit. This system had built in use Benefit Cost ratio ( $B C R$ ) method with web base. Decision criteria is from $B C R$ value, product cost, product price, and benefit. From test of 30 respondences, it got $B C R$ value $>1$ for all yarn that used in one product, so the decision that was took from higher product price and benefit priority. The result of local cotton, bali cotton, and panda cotton test got BCR value 1,35. From the result can be concluded that $B C R$ method implementation this system is already correct and effective to increase price and benefit.
\end{abstract}

Keywords: Decision Support System, Benefit Cost Ratio, yarn, knit

\section{PENDAHULUAN}

Perkembangan zaman yang semakin pesat telah memotivasi manusia untuk berinovasi dalam pemanfaatan teknologi informasi. Salah satu inovasi yang dibuat adalah dalam bidang sistem informasi. Salah satu sistem informasi yang banyak ditemui sekarang adalah Sistem Pendukung Keputusan (SPK). Pemilihan benang bisa dilakukan langsung oleh perajut yang biasanya bekerja seorang diri dalam membuat rajutan walaupun dia memiliki sebuah toko. Memilih benang yang tepat akan membantu menghindarkan perajut dari kerugian.

Diharapkan dengan SPK ini perajut dapat lebih mudah dalam memilih benang yang akan digunakan, serta menentukan harga jual, modal dan keuntungan yang diperoleh.

\section{LANDASAN TEORI}

\section{Tinjauan Pustaka}

a. Benefit Cost Ratio Analysis of Organic and Inorganic Rice Crop Production

Pada pembuatan Sistem Pendukung Keputusan ini terdapat penelitian pada jurnal yang membahas tentang Benefit Cost Ratio Analysis of Organic and Inorganic Rice Crop Production. Penelitian ini dilakukan pada bidang pertanian di Paskistan. Pada penelitian ini BCR dihitung secara per hektar di kabupaten Sheikhupura. Data dikumpulkan menggunakan teknik stratified random sampling dari tiga zona penelitian. Pada tugas akhir ini pengumpulan data dilakukan dengan metode wawancara dan observasi. Tugas akhir ini juga terfokus pada pembahasan keuntungan dari nilai BCR yang diperoleh. 
b. Analisis Finansial Budidaya Anggrek Dendrobium

Terdapat penelitian dari jurnal yang membahas tentang Analisis Finansial Budidaya Anggrek Dendrobium. Tujuan penelitian ini adalah untuk mengetahui kelayakan budidaya anggrek dendrobium dari Aspek keuangan di UPTD Balai Benih Induk Hortikultura di Loa Janan. Data dianalisis dengan kriteria investasi sebagai Net Present Value (NPV), Net BC Ratio, Internal Rate of Return (IRR), kemudian dianalisis dengan menggunakan analisis sensitivitas. Pada tugas akhir ini, data hanya dianalisis dengan BCR tanpa melewati proses analisis kriteria investasi. Hal ini disebabkan tidak adanya investasi jangka panjang yang dilakukan.

\section{Benang Rajut}

Benang rajut merupakan bahan baku utama dalam proses pembuatan rajutan. Ada beberapa hal yang harus dipertimbangkan dalam memilih benang untuk membuat rajutan, yaitu warna, tekstur, ukuran benang, ketebalan dan jenis seratnya. Benang rajut tersedia dalam berbagai jenis. Berdasarkan seratnya, benang rajut dibagi tiga, yaitu alami, sintetis, dan campuran.

\section{Analisis Biaya Manfaat (Benefit Cost Analysis/Benefit Cost Ratio)}

Metode cost benefit analysis atau benefit cost ratio (BCR) merupakan metode untuk mengevaluasi suatu proyek dengan membandingkan nilai sekarang (present value) dari seluruh manfaat/keuntungan yang diperoleh dengan nilai sekarang dari seluruh biaya proyek tersebut. Berdasarkan BCR, kriteria keputusan proyek didasarkan pada proyekproyek yang memberikan nilai keuntungan yang lebih besar dari biayanya. Analisis Benefit Cost Ratio dirumuskan sebagai berikut:

$$
\begin{aligned}
& \text { Gross } M \text { Mrgin }=\text { Gross Retum }- \text { Cost }_{\text {total }} \\
& \text { Cost }_{\text {total }}=\text { Cost }_{1}+\text { Cost }_{2}+\cdots+\text { Cost }_{n}
\end{aligned}
$$

Dari persamaan di atas dapat dirumuskan Benefit Cost Ratio sebagai berikut:

$$
B C R=\frac{\text { Gross Margin }}{\text { Cost }_{\text {total }}}
$$

di mana:

Gross Margin = selisih antara nilai balik (gross return) dan biaya total

Cost total = total biaya

Cost C $_{1} \quad=$ biaya pertama

$\mathrm{n} \quad$ = biaya ke sekian

Sumber: Jurnal Y. Mehmood dkk, University of Sargodha, Pakistan, Pakistan Journal of Science, Vol. 63 No. 3 September, 2011, hal: 174

Nilai gross return berbanding lurus dengan nilai gross margin. Semakin besar nilai gross return, semakin besar pula nilai gross margin yang diperoleh. 


\section{PERANCANGAN SISTEM}

\section{Perancangan Perangkat lunak}

a. Diagram Konteks

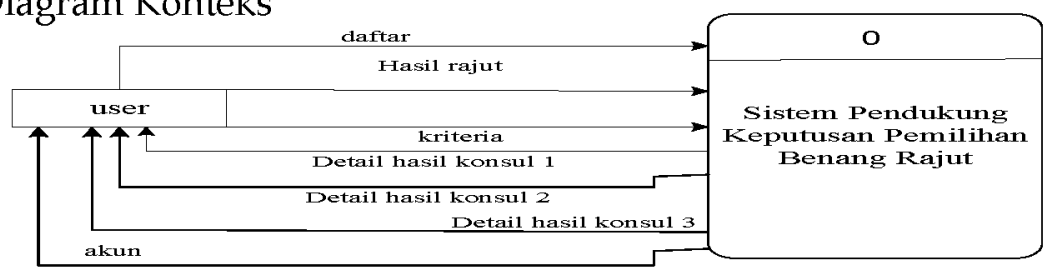

Gambar 1 Diagram Konteks

b. DFD Level 0 SPK Pemilihan Benang Rajut

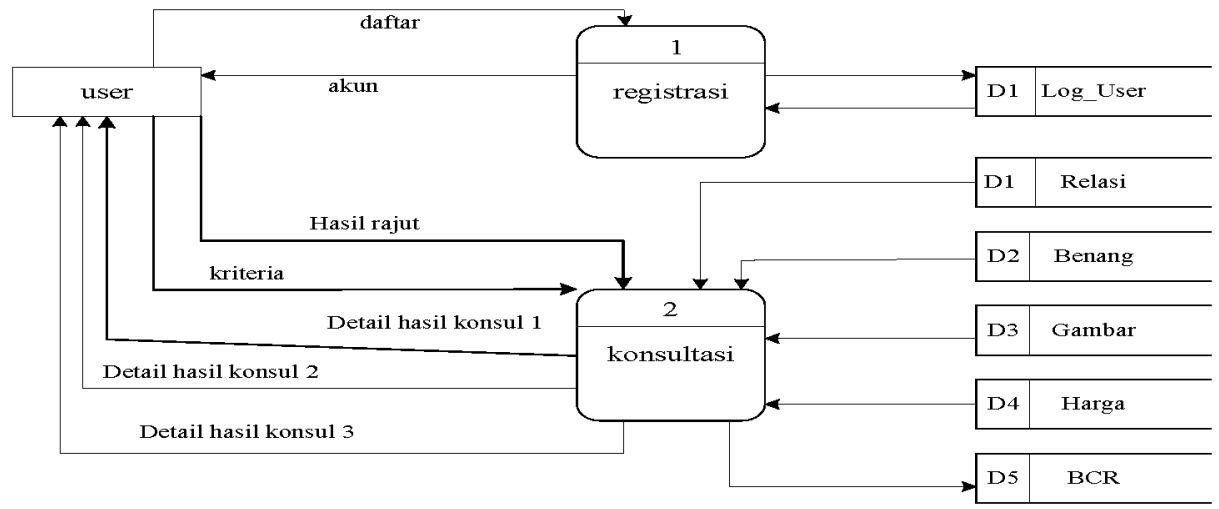

Gambar 2 DFD Level 0

c. DFD Level 1 Proses Registrasi

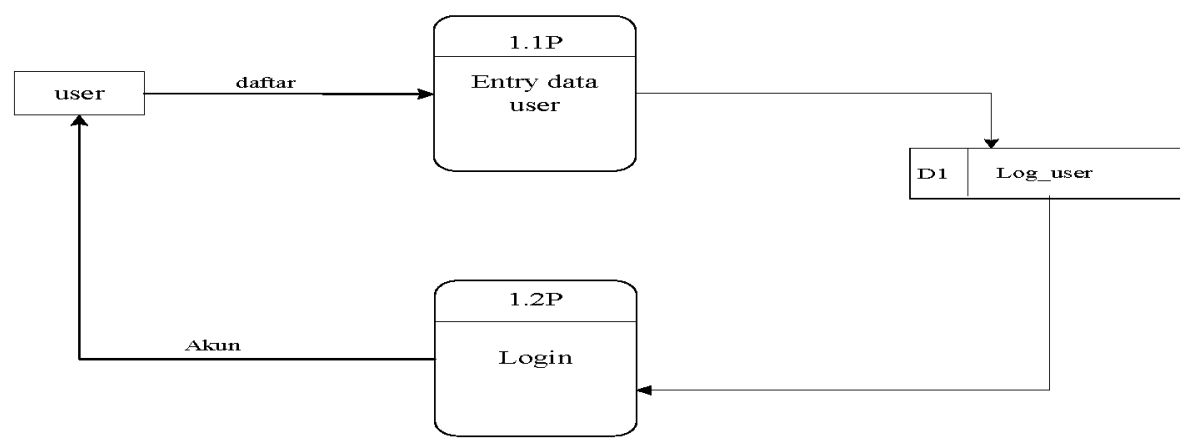

Gambar 3 DFD Level 1 Proses registrasi 
d. DFD Level 1 Proses Konsultasi

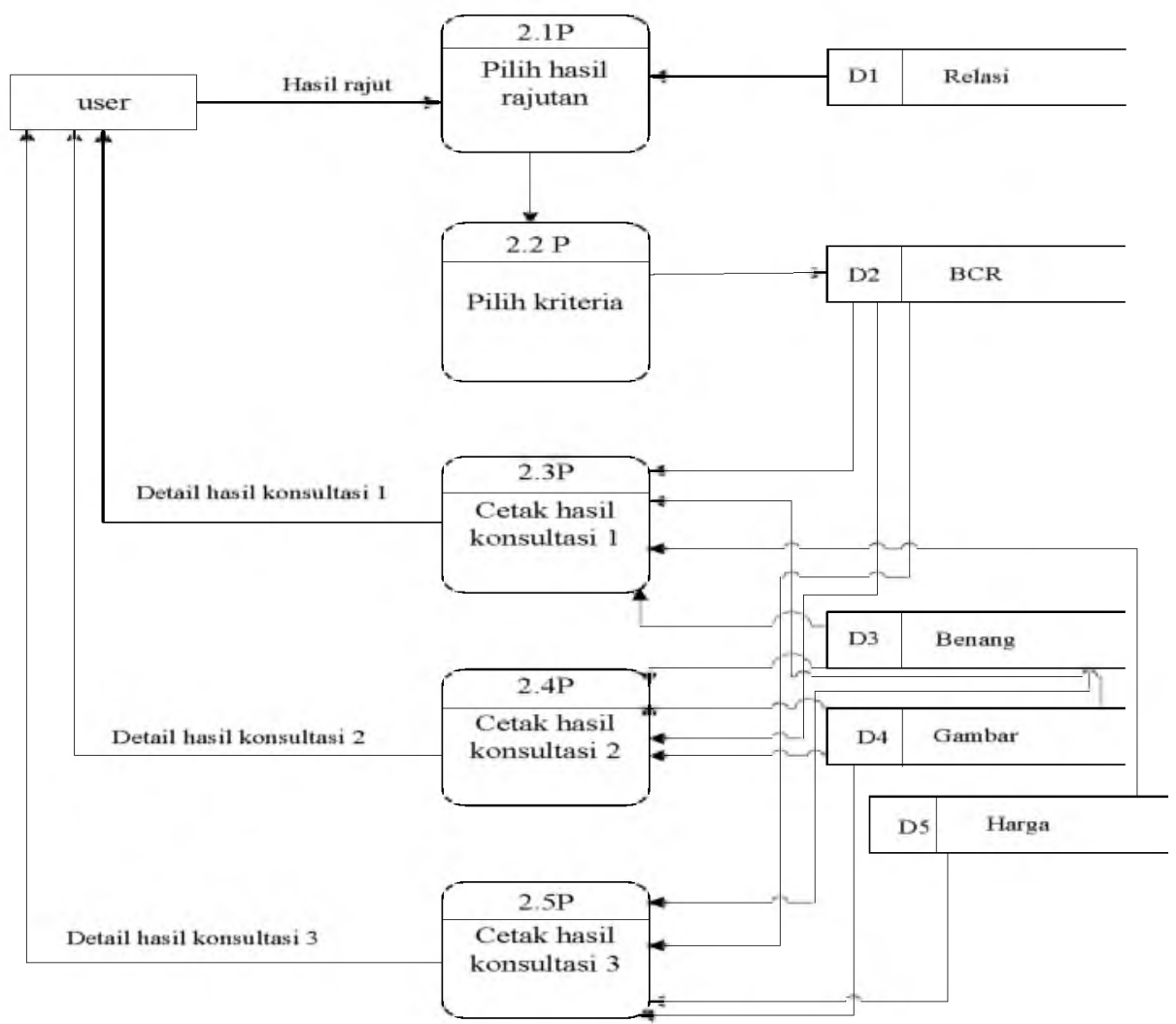

Gambar 4 DFD Level 1 Proses konsultasi

\section{IMPLEMENTASI}

\section{User Home}

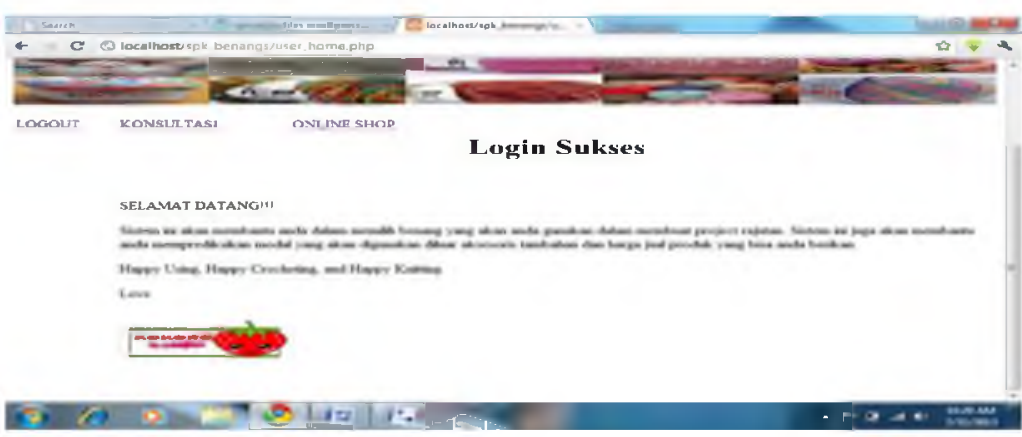

Gambar 4 User Home

User home adalah menu user yang hanya dapat diakses jika id user dan password yang digunakan untuk login benar. User home ini mempunyai beberapa menu, antara lain logout, konsultasi, dan online shop. Menu logout digunakan untuk keluar dari user home. Menu konsultasi digunakan untuk mulai memilih benang. Menu online shop digunakan untuk melihat daftar penjual benang secara online. 


\section{Proses Konsultasi}

a. Pilih Hasil Rajutan

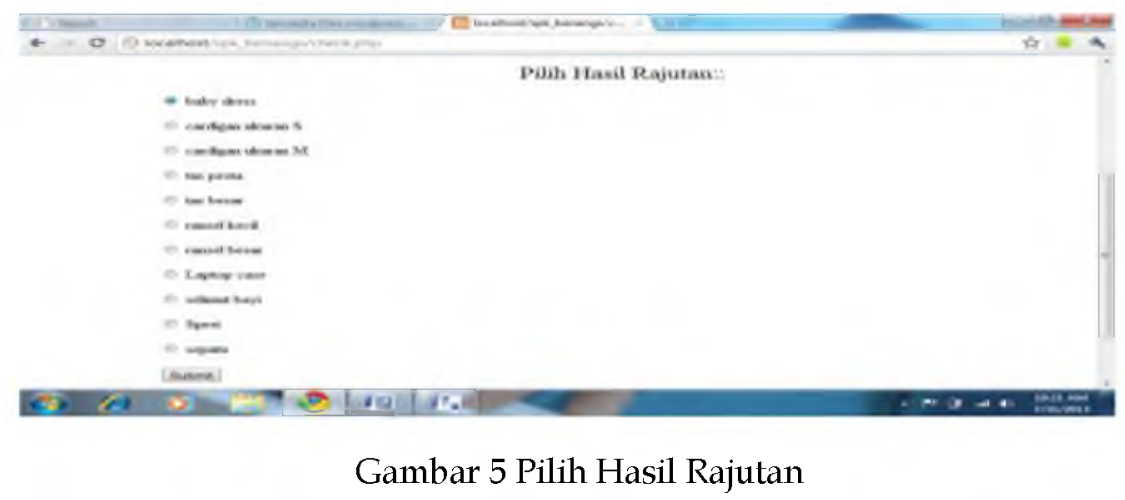

Menu konsultasi digunakan user untuk mulai memilih benang. Pemilihan benang diawali dengan memilih hasil rajutan yang tersedia. Jika user telah memilih salah satu hasil rajutan, user harus mengklik tombol submit untuk masuk ke proses selanjutnya.

b. Pilih Kriteria

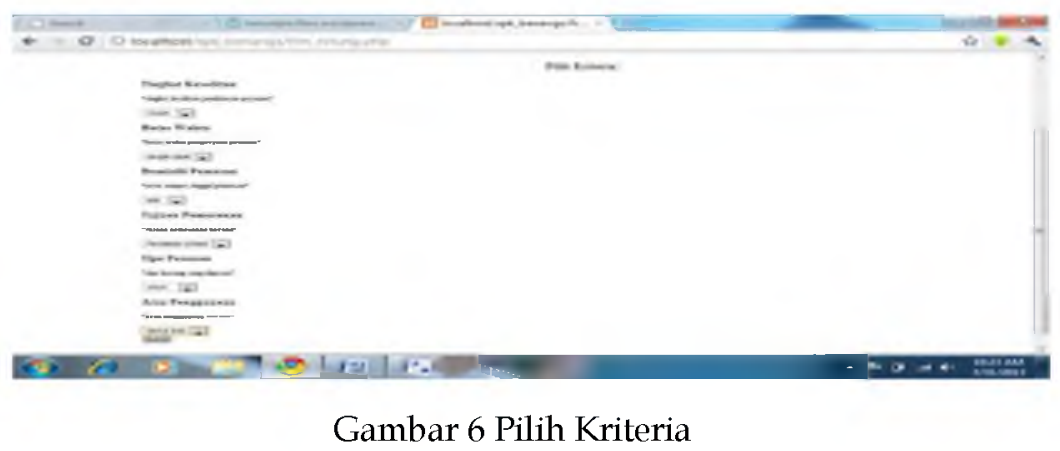

Pemilihan kriteria ini merupakan proses kedua dari pemilihan benang. kriteria-kriteria ini digunakan untuk membantu user dalam menentuan harga produk. Terdapat beberapa kriteria yang masing-masing pilihannya memiliki bobot tertentu yang sifatnya statis, tidak berubah meskipun terjadi kenaikan harga.

\section{Hasil Konsultasi}

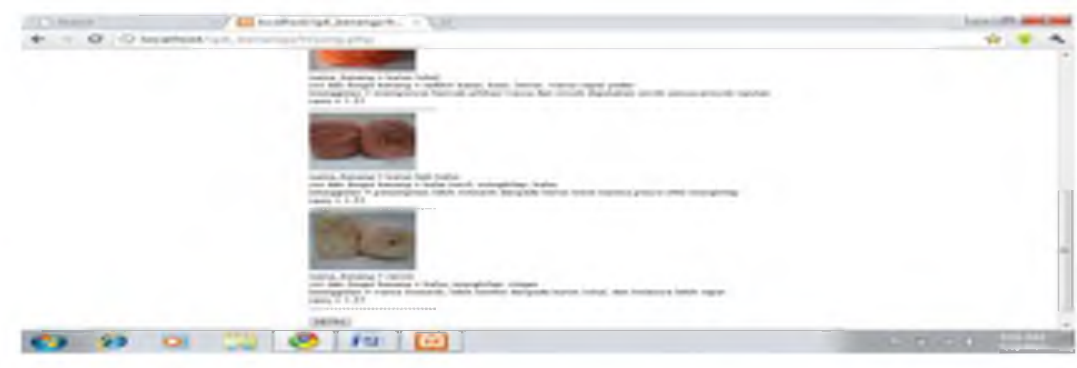

Gambar 6 Hasil Konsultasi

Hasil konsultasi ini menampilkan beberapa data rekomendasi benang untuk dipilih oleh user. Data ini meliputi nama benang, ciri dan fungsi benang, keunggulanbenang secara fisik, gambar fisik benang, dan rasio perhitungan. 


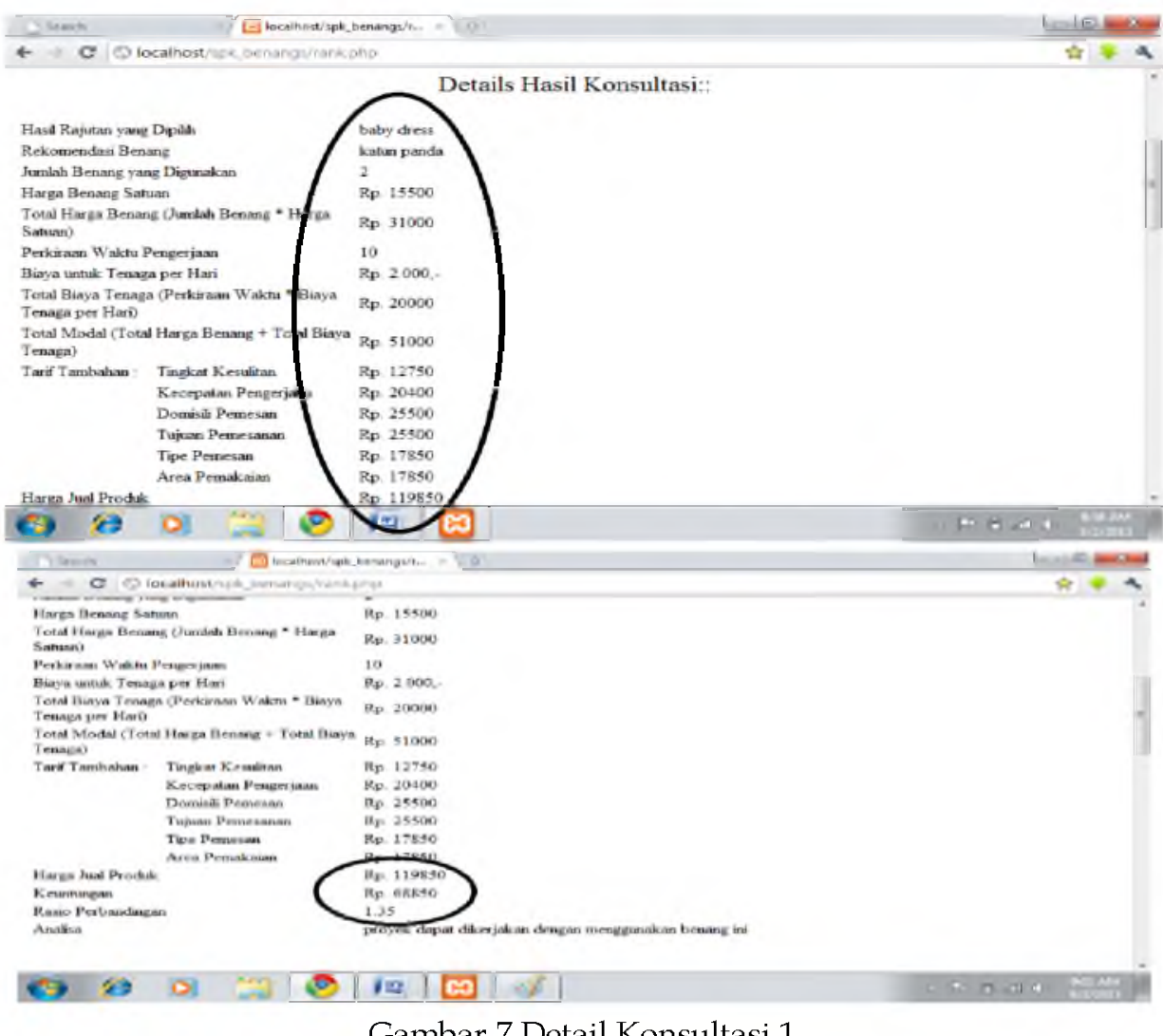

Gambar 7 Detail Konsultasi 1

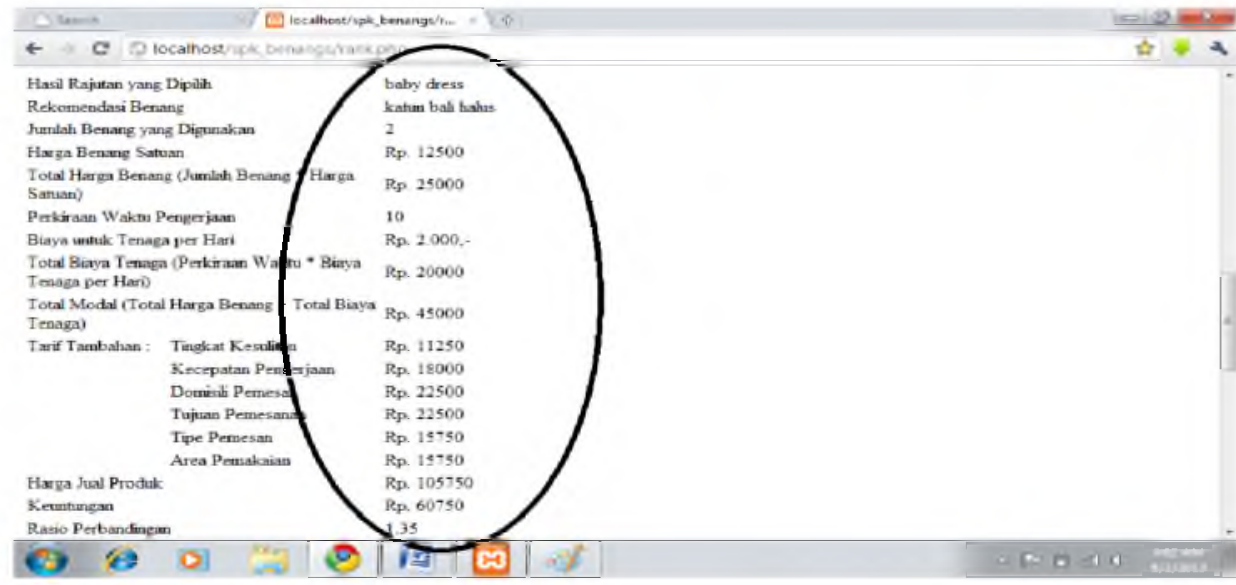

Gambar 8 Detail Konsultasi 2

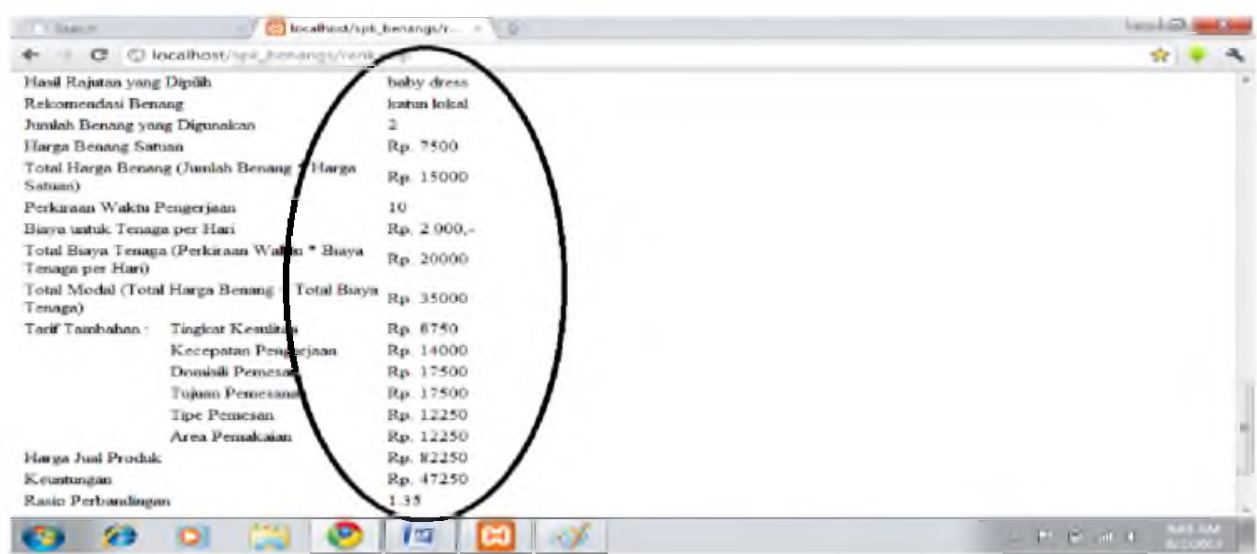

Gambar 9 Detail Konsultasi 3 


\section{ANALISA}

Pengujian dilakukan oleh 30 responden dan diberikan kuisioner untuk mengetahui tingkat kepuasan pengguna.

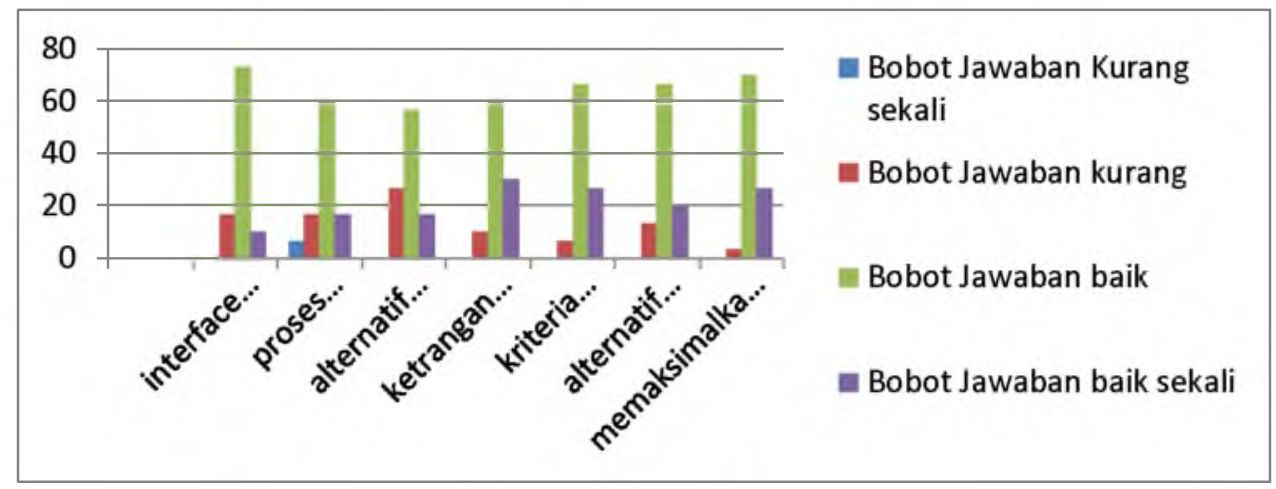

Gambar 12 Grafik Batang

Dari Gambar 12 dapat dinyatakan bahwa pengguna merasa puas dengan sistem yang dibuat.

\section{KESIMPULAN DAN SARAN}

\section{Kesimpulan}

1. Pemilihan benang dilakukan dengan melihat hasil konsultasi yang menunjukkan nilai BCR dari produk yang akan dibuat. Hasil uji katun lokal, katun bali, dan katun panda diperoleh nilai BCR sebesar 1,35. Analisa nilai BCR $>1$ menunjukkkan bahwa benang yang terpilih layak untuk digunakan dalam proyek tersebut.

2. Sistem dikemas dalam bentuk web yang user friendly untuk memudahkan user dalam mengakses dan menggunakan sistem.

3. Dari uji kuisioner terhadap 30 responden dinyatakan bahwa user merasa puas dengan sistem yang dibuat.

\section{Saran}

Sistem ini dapat dikembangkan menjadi sistem yang lebih dinamis dan penggunaan metode lain yang mengarah kepada sistem pakar.

\section{DAFTAR PUSTAKA}

HM, Jogiyanto, MBA, Akt., Analisis dan Desain Sistem Informasi: Pendekatan Terstruktur Teori Dan Praktik Aplikasi Bisnis, Penerbit Andi, Yogyakarta.

Maricar, Noor Sahib, 2005, Oracle SQL Simplified, Penerbit Ekuator Digital Printing, Jakarta.

Mehmood, Y., dkk, 2011, Benefit Cost Ratio Analysis Of Organic And Inorganic Rice Crop, Pakistan, Pakistan Journal of Science, Vol. 63 No. 3 September, 2011, hal: 174, University of Sargodha, Pakistan.

Purwati, Safrida, Dyah Dyanita, 2008, Merajut Yuk!, Penerbit PT. Gramedia Pustaka Utama, Jakarta.

Rahman, Dzul Fadli dan Juraemi, 2008, Analisis Finansial Budidaya Anggrek Dendrobium, EPP. Vol.5 No. 2, hal: 12-17, Fakultas Pertanian, Universitas Mulawarnan, Samarinda.

Hoffer, Jeffrey A. dkk, 2005, Modern Systems Analysis and Design (fourth edition), Prentice Hall 
Vetta Primas tara Terryliani, Anton Setiawan H., Yuliani Indrianingsih 